\section{Serological evidence of canine arthropod-borne infections in an ecotone area of a natural reserve at the Pantanal, Brazil}

\author{
Evidência sorológica de infecções transmitidas por artrópodes \\ caninos em uma área de ecótono de uma reserva natural no \\ Pantanal, Brasil
}

\author{
Bruno Ricardo Soares Alberigi da Silva' (D), Norma Labarthe ${ }^{2}$ (D) Flávia de Oliveira Cardoso ${ }^{3}$ (D), \\ Caroline Magalhães Cunha ${ }^{3}$ (D). Caroline Almeida de Carvalho ${ }^{4}$ (D) , Flavya Mendes-de-Almeida ${ }^{5}$ (D) \\ \& Celeste da Silva Freitas de Souza ${ }^{6}$ (1)
}

'Veterinary, Doctorate, MSc. Programa de Pós-graduação em Medicina Veterinária - PPGMV, Universidade Federal Rural do Rio de Janeiro - UFRRJ, Seropédica, RJ, Brasil

2Professor. Programa de Pós-graduação em Bioética, Ética Aplicada e Saúde Coletiva, Escola Nacional de Saúde Pública Sérgio Arouca - ENSP, Fundação Oswaldo Cruz, Rio de Janeiro, RJ, Brasil

${ }^{3}$ MSc. Laboratório de Imunomodulação e Protozoologia, Instituto Oswaldo Cruz - IOC, Fundação Oswaldo Cruz - Fiocruz, Rio de Janeiro, RJ, Brasil

4Doctor. Laboratório de Imunomodulação e Protozoologia, Instituto Oswaldo Cruz - IOC, Fundação Oswaldo Cruz - Fiocruz, Rio de Janeiro, RJ, Brasil

${ }^{5}$ Professor. Departamento de Patologia e Clínica Veterinária, Universidade Federal Fluminense - UFF, Niterói, RJ, Brasil ${ }^{6}$ Doctor. Laboratório de Imunomodulação e Protozoologia, Instituto Oswaldo Cruz - IOC, Fundação Oswaldo Cruz - Fiocruz, Rio de Janeiro, RJ, Brasil

\begin{abstract}
Arthropod-borne infections are dependent on environmental conditions; therefore, anthropomorphic meddling may disrupt the natural balance that maintains wildlife. It is common to find dogs roaming in Brazilian natural reserves, what favors the spillover of pathogens among species. The aim of this study was to determine the canine seroprevalence of Ehrlichia canis, E. ewingii, Anaplasma platys, A. phagocytophilum, Borrelia burgdorferi, Leishmania infantum and Dirofilaria immitis using 84 serum samples from dogs from the border area of the SESC-Pantanal reserve (RPPN SESC-Pantanal 160 $40^{\prime} 1^{\prime \prime}$ S;56017 '45 ' 'W) stored at the Laboratório de Protozoologia e Imunomodulação, Instituto Oswaldo Cruz. Samples were tested with SNAP ${ }^{\circledR}$ Canine Leishmania Antibody Test (IDEXX Laboratories) or DPP ${ }^{\circledR}$ canine visceral leishmaniasis test (Bio-Manguinhos) for the presence of $L$. infantum antibodies and with SNAP ${ }^{\circledR}$ 4Dx Plus Test (IDEXX Laboratories) for D. immitis, Ehrlichia spp., Anaplasma spp. and B. burgdorferi seroprevalences. The seroprevalence for tick-borne parasites was $79.8 \%, 13.1 \%$ for $L$. infantum and 7.1\% for D. immitis. Since tick-borne parasites were the most frequent among the examined dogs it may be suggested that these parasites, ticks and hosts display special resilience skills to overcome the hostile local conditions. The low L. infantum prevalence suggests that the local biodiversity, especially the bird abundance, depurates Leishmania circulation. The mosquito-borne $D$. immitis prevalence was higher than expected, suggesting that the local flooding regime provides suitable mosquito-breeding spots. On the other hand, the only known vector in the area feeds on birds, therefore reducing mosquitoes worm burden and imparing D. immitis transmission.
\end{abstract}

Keywords: vector-borne diseases, biodiversity, environment, natural reserve.

\section{Resumo}

Infecções transmitidas por artrópodes são dependentes das condições ambientais, portanto, alterações antropomórficas podem romper o equilibrio natural que mantém a vida selvagem. É comum encontrar cães vagando nas reservas naturais brasileiras, o que favorece a adaptação interespecífica de patógenos. O objetivo deste estudo foi determinar a soroprevalência de Ehrlichia canis, E. ewingii, Anaplasma platys, A. phagocytophilum, Borrelia burgdorferi, Leishmania infantum e Dirofilaria immitis utilizando 84 amostras de soro obtidas de cães do ecótone da Reserva SESC-Pantanal (RPPN SESC-Pantanal. 160 $40^{\prime} 51^{\prime \prime}$ S;56017 $45^{\prime \prime}$ 'W). As amostras foram testadas por SNAP ${ }^{\circledR}$ Canine Leishmania Antibody Test (IDEXX Laboratories) ou pelo teste DPP ${ }^{\circledR}$ leishmaniose visceral canina (Bio-Manguinhos) para detecção de anticorpos contra L. infantum e por SNAP ${ }^{\circledR}$ 4Dx Plus Test (IDEXX Laboratories) para detecção de
How to cite: Alberigi, B.R.S., Labarthe, N., Cardoso, F. O., Cunha, C. M., Carvalho, C.A., Mendes-deAlmeida, F., \&Souza, C. S. F. Serological evidence of canine arthropod-borne infections in an ecotone area of a natural reserve at the Pantanal, Brazil. Brazilian Journal of Veterinary Medicine, 41, e103719. https://doi.org/10.29374/2527-2179.bjvm103719

Financial support: The tests were donated by the manufacturers, Idexx Laboratories, São Paulo, SP, Brasil and BioManguinhos, Rio de Janeiro, RJ, Brasil. RPPN SESC-Pantanal funded trips to the Pantanal.

Conflict of interests: No conflict of interests declared concerning the publication of this article.

Received: February 19, 2019.

Accepted: July 23, 2019.

The study was out at Reserva Particular do Patrimônio Natural (reserve), Pantanal, Brazil and maintained in the Laboratório de Imunomodulação e Protozoologia do Instituto Oswaldo Cruz, Rio de Janeiro, RJ, Brasil.

\section{*Correspondence}

Bruno Ricardo Soares Alberigi da Silva Programa de Pós-graduação em Medicina Veterinária - PPGMV, Universidade Federal Rural do Rio de Janeiro - UFRRJ Rodovia BR 465, Km 07, s/n Zona Rural, Campus Seropédica, CEP 23890-000 - Seropédica (RJ), Brasil E-mail: bruno.alberigi@gmail.com

Copyright Alberigi et al. This is an Open Access article distributed under the terms of the Creative Commons Attribution Non-Commercial License which permits unrestricted non-commercial use, distribution, and reproduction in any medium provided the original work is properly cited. 
D. immitis, Ehrlichia spp., Anaplasma spp. e B. burgdorferi. A soroprevalencia para doenças transmitidas por carrapatos foi $79.8 \%, 13.1 \%$ para $L$. infantum e $7.1 \%$ para D. immitis.. Como os parasitos transmitidos por carrapatos foram os mais frequentes, é possível sugerir que estes parasitos, carrapatos e hospedeiros sejam resilientes para superar a hostilidade do Pantanal. A soroprevalência de L. infantum foi baixa, sugerindo que a biodiversidade, especialmente a abundância avícola, depure a circulação de Leishmania, reduzindo o risco da ocorrência de leishmaniose visceral. A prevalência de $D$. immitis foi relativamente alta, sugerindo que as enchentes do Pantanal possam prover criadouros para os mosquitos. Além disso, o único vetor competente da área é atraído por aves, o que pode diminuir a transmissão do parasito para a população canina.

Palavras-chave: doenças transmitidas por vetores, biodiversidade, meio ambiente, reserva natural.

\section{Introduction}

Besides the close living of domestic animals and wildlife, global climate changes favors arthropods dispersion and colonization in new areas worldwide. Consequently there is an expected arthropod-borne diseases spread, which imposes the need for continuous surveillance (Beugnet \& Chalvet-Monfray, 2013; Dantas-Torres, 2015). Mosquitoes and ticks are the two leading arthropod groups in transmitting different pathogens to domestic animals, wildlife and humans (Brites-Neto et al., 2015; Adhikari, 2018). Among these vectors, sandflies must be mentioned once they vector Leishmania infantum, a parasite that infects and threats the lives of more than a million humans/year (Lainson \& Rangel, 2005; World Health Organization, 2015).

Among the most frequently detected canine arthropod-borne parasites worldwide are Ehrlichia canis, Anaplasma phagocytophilum, Anaplasma platys, Borrelia burgdorferi, Leishmania infantum and Dirofilaria immitis, (Labarthe et al., 2003; Bowman et al., 2009; Villeneuve et al., 2011; Cardoso et al., 2012; Day, 2011). D. immitis dispersion is favored by its capacity of being vectored by many different mosquito species (Ludlam et al., 1970) while the bacteria and the protozoan demand specific vectors (Vieira et al., 2011). Even in face of this demand E. canis, E. ewingii, A. platys, A. phagocytophilum, L. infantum, and B. burgdorferi infect diverse mammalian hosts and circulate in different areas of the world (Sykes, 2014; Lainson \& Rangel, 2005; Akhoundi et al., 2016).

In Brazil, as in other South American countries, D. immitis and E. canis are the most prevalent arthropod-borne parasites (Labarthe et al., 2018; Bendas et al., 2017; Willi, et al., 2017; Labarthe et al., 2014; Vezzani et al., 2011; Guilarte et al., 2011; Melo et al., 2011; Aguiar at al., 2007; Vieira et al., 2011). This wide distribution of $E$. canis is probably due to the fact that its vector is the wide-spread Rhipicephalus sanguineus (Miranda \& Máttar, 2015; Vieira et al., 2011; Dantas-Torres, 2008), a prevalent species all over Brazil (Labruna \& Pereira 2001). On the other hand A. phagocytophilum and B. burgdorferi are vectored by the Ixodes ricinus complex (Nieto \& Foley, 2009) and E. ewingii by Amblyomma americanum ticks either rare or erroneously reported in Brazil (Dantas-Torres et al., 2009), therefore ehrlichiosis and anaplasmosis of Brazilian dogs are most probably due to E. canis and A. platys infections. Although rare, E. ewingii, A. phagocytophilum or B. burgdorferi canine infections have been documented (Santos et al., 2011; Silveira et al., 2015; Cordeiro et al., 2012; Montandon et al., 2014, Vieira et al., 2011). L. infantum is endemic in Latin America, Asia, Middle East and in the Mediterranean basin (Leblois et al., 2011). In the Americas it is mainly transmitted by Lutzomyia longipalpis (Lainson \& Rangel, 2005), a different vector species from the Old World (Senghor et al., 2011).

E. canis infections are widely distributed among domestic and wild canids (Sykes, 2014). It is known to be widely spread in the Brazilian territory (Vieira, et al., 2011). A national survey showed dot-ELISA seroprevalence of 19.8\%, confirming that the bacterium is present in all Brazilian geographic regions (Labarthe et al., 2003) and local surveys using various diagnostic tests and different canine populations have been published confirming its wide distribution (Macieira et al., 2005; Oliveira et al., 2000; Aguiar et al., 2007; Souza et al., 2010; Silva et al., 2010). A survey conducted in the Pantanal biome showed that in both urban and rural areas the majority of dogs were seropositive for $E$. canis (70.9\%), with similar infection rates in both environments (Melo et al., 2011). E. ewingii is seldom reported in Brazil although molecular analysis detected five infected dogs (Oliveira et al., 2009). 
A. platys is also wide spread worldwide (Sykes \& Foley, 2014). In Brazil its known prevalence ranges from 10.3\% to 15.8\% (Sales et al., 2007; Ferreira et al., 2007). It must be emphasized that 160 of the 2.861 dogs' blood samples from an urban area of the Pantanal area were shown to be infected by A. platys (Sales et al., 2007).

The Brazilian canine L. infantum prevalence varies from 19\% to $40.3 \%$ in the Northeastern region (Dantas-Torres et al., 2006; Figueredo et al., 2017) and from 12 to 30\% in the Southeastern region (Figueredo et al., 2017). In an urban area of the Pantanal (Mid-Western region) the known prevalence of leishmaniasis is 61.7\% (Moura et al., 1999).

The definitive hosts of $D$. immitis are canids, although other mammals can be infected. Brazilian D. immitis prevalence varied over time from 7.9\% (Guerrero et al., 1989) to 2\% (Labarthe et al., 2003) and afterwards rebounded to $23.1 \%$ showing hyperenzootic areas with infection rate of 62\% (Labarthe et al., 2014). In the urban area of Cuiabá, at the Pantanal, the known prevalence is only $1 \%$ (Ramos et al., 2015).

Therefore, since there are different arthropod-borne parasites infecting dogs in various Brazilian areas and because the close living of dogs and wildlife favors the spillover of bioagents that can affect wildlife, domestic animals and humans, the aim of this survey was to investigate if the canine population living by an ecotone presented serologic evidence of arthropod-borne pathogens infections.

\section{Material and methods}

The Pantanal is the largest wetland area of the world, covering approximately $170,000 \mathrm{~km}^{2}$. During the flooding season animals are trapped in smaller dry areas where they share resources, vectors and parasites intimately. When drought arrives they roam around the entire environment, therefore dispersing parasites and vectors (Bechara et al., 2000; Martins et al., 2004; Labruna et al., 2005). The "reserve", Reserva Particular do Patrimônio Natural (RPPN SESC- Pantanal) is a 87,871 hectares area in the Pantanal (North - 16028`31"S and 56017'49"W; East - 16042`30"S

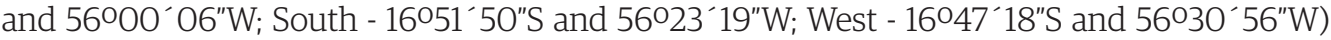
(Figure 1) harboring approximately 95 mammalian species and 340 bird species among other animal groups (Alho et al., 1987, 2011; Marchini, 2003; Brandão et al., 2011). There are two villages

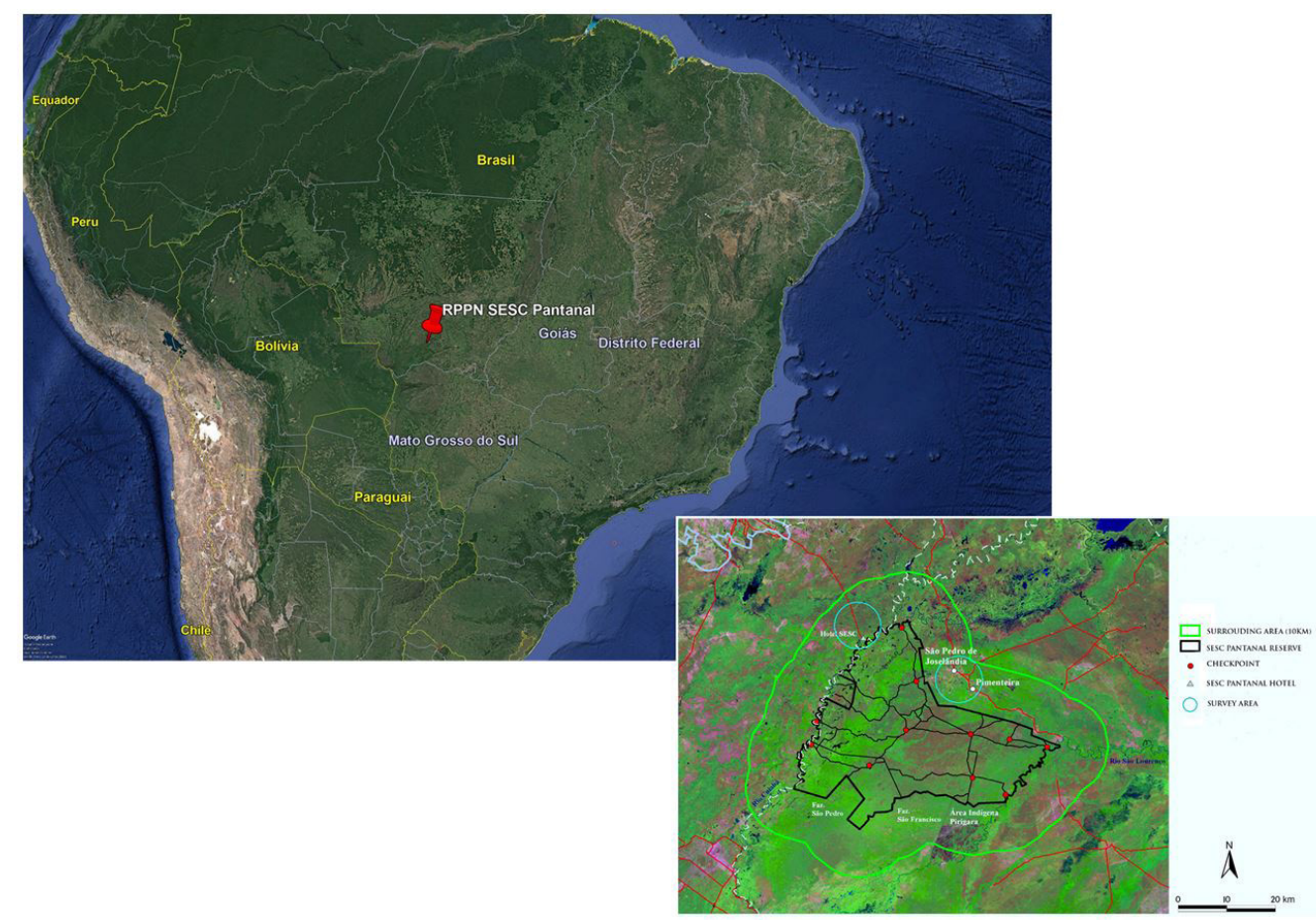

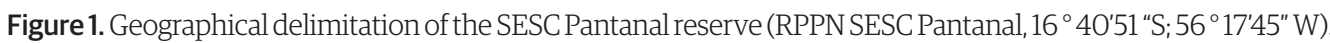
Source: Fiocruz (2012). 
on the edge of the reserve and, given that human groups keep dogs as pets or for hunting, it is not uncommon to find dogs roaming in the reserve.

Serum samples obtained non probabilistically by convenience from 84 dogs living on the edge of the Reserva Particular do Patrimônio Natural (reserve), Pantanal, Brazil and maintained in the Laboratório de Imunomodulação e Protozoologia do Instituto Oswaldo Cruz (Authorization LW-16/10- CEUA/Oswaldo Cruz Foundation) at -20 ${ }^{\circ} \mathrm{C}$ were used.

Samples were tested with the $\mathrm{DPP}{ }^{\circledR}$ canine visceral leishmaniasis test (Bio-Manguinhos, Brazil) or with the SNAP ${ }^{\circledR}$ Leishmania antibody test (IDEXX Laboratories, Inc., Maine, USA) for detection of antibodies against $L$. infantum and with SNAP ${ }^{\circledR}$ 4Dx Plus (IDEXX Laboratories, Inc., USA) for detection of D. immitis antigens; E. canis or E. ewingii antibodies; A. platys or A. phagocytophilum antibodies; and B. burgdorferi antibodies. The serum samples were taken from the freezer in batches of approximately 10 units and used after achieving room temperature. Each test was carried out according to the manufacturer's recommendations.

The number of positive or negative samples for each parasite was recorded on Microsoft excel spread sheet.

\section{Results}

The overall prevalence of the pathogens was 79.8\% (67/84) for tick-borne parasites antibodies, 13.1\% (11/84) for L. infantum antibodies and 7.1\% (6/84) for D. immitis infection. No dog was found to be seroprevalent to all surveyed parasites and 14 were seronegative to all of them (16.7\%). There were 40 dogs with evidence of single infections: for Ehrlichia spp. (34/40-85\%); for Anaplasma spp. (3/40-7.5\%); for L. infantum (2/40-5\%) and for D. immitis (1/40-2.5\%). The 30 dogs with evidence of co-infections presented antibodies against Ehrlichia spp.: for Ehrlichia spp. and Anaplasma spp. (16/30-53.3\%); for Ehrlichia spp. and L. infantum (6/30-20\%); for Ehrlichia spp. and D. immitis (4/30-13.3\%); for Ehrlichia spp., Anaplasma spp. and L. infantum (2/30-6.7\%); for Ehrlichia spp.,

Table 1. Number of dogs living on an ecotone area of the Brazilian Pantanal according to serology results for Ehrlichia spp. (Ehr); Anaplasma spp. (Anap); Borrelia burgdorferi (B); Leishmania infantum (Leish) and Dirofilaria immitis (Di).

\begin{tabular}{|c|c|c|c|c|c|c|c|c|c|c|}
\hline \multirow[b]{2}{*}{ SNeg } & \multicolumn{10}{|c|}{ Serological results } \\
\hline & Ehr & Anap & Leish & Di & $\begin{array}{l}\text { Ehr+ } \\
\text { Anap }\end{array}$ & $\begin{array}{c}\text { Ehr+ } \\
\text { Anap+B }\end{array}$ & $\mathrm{Di}+\mathrm{Ehr}$ & $\begin{array}{c}\text { Di+ Ehr+ } \\
\text { Anap+Leish }\end{array}$ & $\begin{array}{c}\text { Ehr+Anap + } \\
\text { Leish }\end{array}$ & Ehr+ Leish \\
\hline 14 & 34 & 3 & 2 & 1 & 16 & 1 & 4 & 1 & 2 & 6 \\
\hline
\end{tabular}

SNeg: seronegative.

Anaplasma spp. and B. burgdorferi (1/30-3.4\%); and for Ehrlichia spp., Anaplasma, spp., L. infantum and D. immitis (1/30-3.4\%) (Table 1).

\section{Discussion}

It is well known that landscape influences population density, diversity and movement patterns of parasites, vectors and hosts. In the Pantanal, a biome that alternates flooding with very hot temperature $\left(40^{\circ} \mathrm{C}\right.$ ) with droughts when temperature can change from $30^{\circ} \mathrm{C}$ to $10^{\circ} \mathrm{C}$ in 24 hours (Brandão et al., 2011), seasons act as a strong dynamics changing force.

Tick-borne parasites were by far the most frequent among the examined dogs (79.8\%), suggesting that these parasites, ticks and hosts display special resilience skills to overcome the variable and hostile conditions of the Pantanal. Since $R$. sanguineus, the main vector of the most prevalent arthropod-borne parasite detected (Ehrlichia spp), is a tick species known to present catholic feeding habits and to be able to adopt different strategies to survive in rough conditions (Labruna et al., 2005; Dantas-Torres et al., 2010), it is possible to infer that they can overcome the flooding season finding alternative refuges and uncommon hosts. Although not especially attractive to R. sanguineus, capybaras (Hydrochaeris hydrochaeris) can host those ticks (Fernanda Passos Nunes, personal communication) therefore; R. sanguineus survival strategy could include infesting the Brazilian Rickettsia rickettsii efficient amplifier capybara (Krawczak et al., 2014). Since 
R. sanguineus can get infected with $R$. rickettsii (Piranda et al., 2011) among other parasites, it may be suggested that the domestic dogs of the villages are exposed to the risk of being infected by this tick-borne pathogen. In face of the global climatic changes this may become a public health concern because tick's attraction towards humans is enhanced in high temperatures (Parola et al., 2008).

The unexpected finding of a $B$. burgdorferi seropositive dog raises the question on which species could be the local competent vector as well as the local competent reservoir of the bacterium. The detected antibody is produce towards $\mathrm{C}_{6}$ peptide a marker only expressed when the bacterium is transmitted to the dog and known to be specific (Marques et al., 2002; Littman et al., 2006). Therefore and mainly because local biodiversity is still to be completely unveiled, further surveys must be conducted to elucidate B. burgdorferi ecology in the Pantanal.

The observed $L$. infantum seroprevalence was lower than expected for the Pantanal even though no culling of seropositive dogs nor insecticide spraying were carried out at the surveyed villages. Since there was no direct human interference on local L. infantum infection-rate in the villages, it can be speculated that the complexity of the biodiversity of the area must have diluted the risk of infection either by diminishing competent vectors abundance or by offering an enormous richness of $L$. infantum refractory hosts in which $L u$. longipalpis feeds on. It is well known that these sandflies are strongly attracted to birds (Lainson \& Rangel, 2005), that L. infantum infects only a narrow range of mammal species (Lainson \& Rangel, 2005) and that the abundance and richness of birds in the Pantanal is astonishing (Signor \& Pinho, 2011), suggesting that birds might play a key role for the natural control of the number of canine $L$. infantum infections in the area.

The only mosquito vectored parasite surveyed, $D$. immitis, was the least seroprevalent, what can, at first sight, suggest low competent vector population or low microfilaremic canids in the area. As a matter of fact, the competent vectors Ochlerotatus scapularis and O. taeniorhynchus were not captured in the reserve or on it 's edge and the only known competent vector genus captured in the area was Culex (unpublished data). Many Culex species are known to blood-feed on birds (Forattini, 2002) therefore, reducing the mosquitos' worm burden. Furthermore, it must be considered that the test kit used detects $D$. immitis active infection and not antibodies as the other surveyed pathogens, what certainly makes seroprevalence lower. Since $D$. immitis was the only medically preventable infection studied and even though $7.1 \%$ of the dogs were infected, it shows that dogs were neglected and received no veterinary care. The trifling way dogs are cared for at the villages enhances the need for health programs in the area to guarantee both wild and domestic animals welfare and human health.

In conclusion it may be said that the abundance and richness of biodiversity of the Pantanal tends to enhance health of all kinds of life, although when a high-density of one host species is observed it may point out to disturbance that are difficult to diagnose or control. That could be the reason why tick-borne diseases were so prevalent while sandfly-borne and mosquito-borne seemed to be under natural control. Furthermore, it is reasonable to suggest that if no action is taken towards environmental care aiming to control capybaras population in the area allied to better peridomestic tick control, a Brazilian Spotted Fever outbreak may occur.

\section{Conclusions}

All the surveyed vector-borne parasites were found to infect the canine population living by the edge of the RPPN SESC- Pantanal. E. canis was the most prevalent pathogen, pointing out to the fact that ticks and tick-borne diseases must receive specific attention in order to promote the one health approach in that important biodiverse environment. These results suggest that the biological richness and abundance of the reserve contribute to human, domestic animals and wildlife welfare in the area.

\section{References}

Adhikari, S. (2018). Arthropods vector in disease transmission. Acta Scientific Agriculture, 2, 166-168.

Aguiar, D. M., Cavalcante, G. T., Pinter, A., Gennari, S. M., Camargo, L. M. A., \& Labruna, M. B. (2007). Prevalence of Ehrlichia canis (Rickettsiales: Anaplasmataceae) in dogs and Rhipicephalus sanguineus (Acari: Ixodidae) ticks from Brazil. Journal of Medical Entomology, 44(1), 126-132. http://dx.doi.org/10.1603/0022-2585(2007)44[126:POE CRA]2.0.CO;2. PMid:17294930. 
Akhoundi, M., Kuhls, K., Cannet, A., Votýpka, J., Marty, P., Delaunay, P., \& Sereno, D. (2016). A Historical Overview of the Classification, Evolution, and Dispersion of Leishmania Parasites and Sandflies. PLoS Neglected Tropical Diseases, 10(3), e0004349. http://dx.doi.org/10.1371/journal.pntd.0004349. PMid:26937644.

Alho, C. J. R., Camargo, G., \& Fischer, E. (2011). Terrestrial and aquatic mammals of the Pantanal. Brazilian Journal of Biology = Revista Brasileira de Biologia, 71(1, Suppl 1), 297-310. http://dx.doi.org/10.1590/S151969842011000200009. PMid:21537603.

Alho, C. J. R., Lacher Junior, T. E., Campos, Z. M. S., \& Gonçalves, H. C. (1987). Mamíferos da Fazenda Nhumirim, sub-região de Nhecolândia, Pantanal do Mato Grosso do Sul. I. Levantamento preliminar de espécies. Revista Brasileira de Zoologia, 4(2), 151-164. http://dx.doi.org/10.1590/S0101-81751987000200007.

Bechara, G. H., Szabó, M. P., Duarte, J. M., Matushima, E. R., Pereira, M. C., Rechav, Y., Keirans, J. E., \& Fielden, L. J. (2000). Ticks associated with wild animals in the Nhecolândia Pantanal, Brazil. Annals of the New York Academy of Sciences, 916(1), 289-297. http://dx.doi.org/10.1111/j.1749-6632.2000.tb05303.x. PMid:11193635.

Bendas, A. J. R., Mendes-de-Almeida, F., Guerrero, J., \& Labarthe, N. (2017). Update on Dirofilaria immitis epidemiology in South America and Mexico: literature review. Pesquisa Veterinária Brasileira, 54, 319-329.

Beugnet, F., \& Chalvet-Monfray, K. (2013). Impact of climate change in the epidemiology of vector-borne disease in domestic carnivores. Comparative Immunology, Microbiology and Infectious Diseases, 36(6), 559-566. http:// dx.doi.org/10.1016/j.cimid.2013.07.003. PMid:23953958.

Bowman, D., Little, S. E., Lorentzen, L., Shields, J., Sullivan, M. P., \& Carlin, E. P. (2009). Prevalence and geographic distribution of Dirofilaria immitis, Borrelia burgdorferi, Ehrlichia canis, and Anaplasma phagocytophilum in dogs in the United States: results of a national clinic-based serologic survey. Veterinary Parasitology, 160(1-2), 138-148. http://dx.doi.org/10.1016/j.vetpar.2008.10.093. PMid:19150176.

Brandão, L. C., Antas, P. T. Z., de Oliveira, L. F. B., Pádua, M. T. J., Pereira, N. C., \& Valutky, W. W. (2011). Plano de Manejo da Reserva Particular do Patrimônio Natural do SESC-Pantanal (2. ed., Conhecendo o Pantanal, Vol. 3,148 p.). Rio de Janeiro: Assessoria de Divulgação e Promoção do SESC.

Brites-Neto, J., Duarte, K. M. R., \& Martins, T. F. (2015). Tick-borne infections in human and animal population worldwide. Veterinary World, 8(3), 301-315. http://dx.doi.org/10.14202/vetworld.2015.301-315. PMid:27047089.

Cardoso, L., Mendão, C., \& Madeira de Carvalho, L. (2012). Prevalence of Dirofilaria immitis, Ehrlichia canis, Borrelia burgdorferi sensu lato, Anaplasma spp. and Leishmania infantum in apparently healthy and CVBD-suspect dogs in Portugal-a national serological study. Parasites \& Vectors, 5(1), 62. http://dx.doi.org/10.1186/1756-33055-62. PMid:22452990.

Cordeiro, M. D., Meireles, G. S., Silva, J. B., Souza, M., \& Fonseca, A. H. (2012). Soroprevalência para Borrelia spp. em cães no município de Seropédica, estado do Rio de Janeiro. Revista Brasileira de Medicina Veterinária, 34, 251-256.

Dantas-Torres, F. (2008). Canine vector-borne diseases in Brazil. Parasites \& Vectors, 1(1), 25. http://dx.doi. org/10.1186/1756-3305-1-25. PMid:18691408.

Dantas-Torres, F. (2015). Climate change, biodiversity, ticks and tick-borne diseases: The butterfly effect. International Journal for Parasitology. Parasites and Wildlife, 4(3), 452-461. http://dx.doi.org/10.1016/j.ijppaw.2015.07.001. PMid:26835253.

Dantas-Torres, F., Brito, M. E. F., \& Brandão-Filho, S. P. (2006). Seroepidemiological survey on canine leishmaniasis among dogs from na urban area of Brazil. Veterinary Parasitology, 140(1-2), 54-60. http://dx.doi.org/10.1016/i. vetpar.2006.03.008. PMid:16621286.

Dantas-Torres, F., Onofrio, V. C., \& Barros-Battesti, D. M. (2009). The ticks (Acari: Ixodida: Argasidae, Ixodidae) of Brazil. Sys. Applied Acarology, 14(1), 30-46. http://dx.doi.org/10.11158/saa.14.1.4.

Dantas-Torres, F., Ferreira, D. R., Melo, L. M., Lima, P. A., Siqueira, D. B., Rameh-de Albuquerque, L. C., Melo, A. V., \& Ramos, J. A. (2010). Ticks on captive and free-living wild animals in northeastern Brazil. Experimental \& Applied Acarology, 50(2), 181-189. http://dx.doi.org/10.1007/s10493-009-9296-5. PMid:19693679.

Day, M. J. (2011). One health: the importance of companion animal vector-borne diseases. Parasites \& Vectors, 4(1), 49. http://dx.doi.org/10.1186/1756-3305-4-49. PMid:21489237.

Ferreira, R. F., Cerqueira, A. M. F., Pereira, A. M., Guimarães, C. M., Sá, A. G., Abreu, F. S., Massard, C. L., \& Almosny, N. R. P. (2007). Anaplasma platys diagnosis in dogs: comparison between morphological and molecular tests. International Journal of Applied Research in Veterinary Medicine, 5, 113-119.

Figueredo, L. A., Sales, K. G. D. S., Deuster, K., Pollmeier, M., Otranto, D., \& Dantas-Torres, F. (2017). Exposure to vector-borne pathogens in privately owned dogs living in different socioeconomic settings in Brazil. Veterinary Parasitology, 243, 18-23. http://dx.doi.org/10.1016/j.vetpar.2017.05.020. PMid:28807290.

Forattini, O. P. (2002). Culicidologia médica (Vol. 2, 864 p.). São Paulo: Edusp.

Guerrero, J., Genchi, C., \& Vezzoni, A. 1989. Distribution of Dirofilaria immitis in selected areas of Europe and South America. In G. F. Otto (Ed.), Proceedings of Heartworm Symposium: Vol. 89 (pp. 13-18). Washington: American Heartworm Society.

Guilarte, D. V., Martinez, E. G., Hen, F. E., Guzman, R., Blondell, D., Díaz, M. T., \& Santiago, J. (2011). Diagnóstico de Dirofilaria immitis em el municipio Sucre, estado Sucre, Venezuela. Boletín de Malariología y Salud Ambiental, 51, 51-58. 
Krawczak, F. S., Nieri-Bastos, F. A., Nunes, F. P., Soares, J. F., Moraes-Filho, J., \& Labruna, M. B. (2014). Rickettsial infection in Amblyomma cajennense ticks and capybaras (Hydrochoerus hydrochaeris) in a Brazilian spotted fever-endemic area. Parasites \& Vectors, 7(1), 7. http://dx.doi.org/10.1186/1756-3305-7-7. PMid:24387674.

Labarthe, N., Paiva, J. P., Reifur, L., Mendes-de-Almeida, F., Merlo, A., Pinto, C. J. C., Juliani, P. S., Almeida, M. A. O., \& Alves, L. C. (2014). Updated canine infection rates for Dirofilaria immitis in areas of Brazil previously identified as having high incidence of heartworm-infected dogs. Parasites \& Vectors, 7(1), 493. http://dx.doi. org/10.1186/s13071-014-0493-7. PMid:25376238.

Labarthe, N., Pereira, M. C., Barbarini, O., McKee, W., Coimbra, C. A., \& Hoskins, J. (2003). Serologic prevalence of Dirofilaria immitis, Ehrlichia canis, and Borrelia burgdorferi infections in Brazil. Veterinary Therapeutics, 4(1), 67-75. PMid:12756637.

Labarthe, N., Rodriguez, N., Couto, G., Mendes-de-Almeida, F., \& Guerrero, J. (2018). A Pilot Survey of VectorTransmitted Diseases in Cartagena and Barranquilla, Colombia. International Journal of Applied Research in Veterinary Medicine, 16, 60-66.

Labruna, M. B., \& Pereira, M. (2001). Carrapato em cães no Brasil. La Clinica Veterinaria, 30, 24-32.

Labruna, M. B., Jorge, R. S., Sana, D. A., Jácomo, A. T., Kashivakura, C. K., Furtado, M. M., Ferro, C., Perez, S. A., Silveira, L., Santos Junior, T. S., Marques, S. R., Morato, R. G., Nava, A., Adania, C. H., Teixeira, R. H., Gomes, A. A., Conforti, V. A., Azevedo, F. C., Prada, C. S., Silva, J. C., Batista, A. F., Marvulo, M. F., Morato, R. L., Alho, C. J., Pinter, A., Ferreira, P. M., Ferreira, F., \& Barros-Battesti, D. M. (2005). Ticks (Acari: Ixodida) on wild carnivores in Brazil. Experimental \& Applied Acarology, 36(1-2), 149-163. http://dx.doi.org/10.1007/s10493-005-2563-1. PMid:16082932.

Lainson, R., \& Rangel, E. F. (2005). Lutzomyia longipalpis and the eco-epidemiology of American visceral leishmaniasis, with particular reference to Brazil - a review. Memorias do Instituto Oswaldo Cruz, 100(8), 811-882. http://dx.doi.org/10.1590/S0074-02762005000800001. PMid:16444411.

Leblois, R., Kuhls, K., François, O., Schönian, G., \& Wirth, T. (2011). Guns, germs and dogs: on the origin of Leishmania chagasi. Infection, Genetics and Evolution, 11(5), 1091-1095. http://dx.doi.org/10.1016/j.meegid.2011.04.004. PMid:21511057.

Littman, M. P., Goldstein, A., Labato, M. A., Lappin, M. R., \& Moore, G. E. (2006). ACVIM small animal conseneue stattement on lyme disease in dogs: diagnosis, treatment, and prevention. Journal of Veterinary Internal Medicine, 20(2), 422-434. http://dx.doi.org/10.1111/j.1939-1676.2006.tb02880.x. PMid:16594606.

Ludlam, K. W., Jachowski Junior, L. A., \& Otto, G. F. (1970). Potential vectors of Dirofilaria immitis. Journal of the American Veterinary Medical Association, 157(10), 1354-1359. PMid:4394832.

Macieira, D. B., Messick, J. B., Cerqueira, A. M. F., Freire, I. M. A., Linhares, G. F. C., Almeida, N. K. O., \& Almosny, N. R. P. (2005). Prevalence of Ehrlichia canis infection in thrombocytopenic dogs from Rio de Janeiro, Brazil. Veterinary Clinical Pathology, 34(1), 44-48. http://dx.doi.org/10.1111/j.1939-165X.2005.tb00008.x. PMid:15732017.

Marchini, S. (2003). Pantanal: opinião pública local sobre meio ambiente e desenvolvimento (40 p.). Belém: Instituto de Desenvolvimento Sustentável Mamirauá.

Marques, A. R., Martin, D. S., \& Philipp, M. T. (2002). Evaluation of the C6 peptide enzyme-linked immunosorbent assay for individuals vaccinated with the recombinant OspA vaccine. Journal of Clinical Microbiology, 40(7), 25914-2593. http://dx.doi.org/10.1128/JCM.40.7.2591-2593.2002. PMid:12089281.

Martins, J. R., Medri, I. M., Oliveira, C. M., \& Guglielmone, A. (2004). Ocorrência de carrapatos em tamanduábandeira (Myrmecophaga tridactyla) e tamanduá-mirim (Tamandua tetradactyla) na região do Pantanal Sul Mato-Grossense, Brasil. Ciência Rural, 34(1), 293-295. http://dx.doi.org/10.1590/S0103-84782004000100048.

Melo, A. L. T., Martins, T. F., Horta, M. C., Moraes-Filho, J., Pacheco, R. C., Labruna, M. B., \& Aguiar, D. M. (2011). Seroprevalence and risk factors to Ehrlichia spp. and Rickettsia spp. in dogs from the Pantanal Region of Mato Grosso State, Brazil. Ticks and Tick-Borne Diseases, 2(4), 213-218. http://dx.doi.org/10.1016/j.ttbdis.2011.09.007. PMid:22108015.

Miranda, J., \& Máttar, S. (2015). Molecular detection of Anaplama sp. and Ebrlichia sp. in ticks collected in domestic animals, Colombia. Tropical Biomedicine, 32, 726-735.

Montandon, C. E., Yoshinari, N. H., Milagres, B. S., Mazioli, R., Gomes, G. G., Moreira, H. N., Padilha, A. F., Wanderley, G. G., Mantovani, E., Galvão, M. A. M., Langoni, H., \& Mafra, C. (2014). Evidence of Borrelia in wild and domestic mammals from the state of Minas Gerais. Revista brasileira de parasitologia veterinaria = Brazilian journal of veterinary parasitology: Orgao Oficial do Colegio Brasileiro de Parasitologia Veterinaria, 23(2), 287-290. PMid:25054516.

Moura, S. T., Fernandes, C. G. N., Pandolpho, V. C., \& Rodrigues e Silva, R. (1999). Diagnóstico de leishmaniose canina na área urbana do município de Cuiabá, estado do Mato Grosso, Brasil. Brazilian Journal of Veterinary Research and Animal Science, 36(2), 101-102. http://dx.doi.org/10.1590/S1413-95961999000200009.

Nieto, N., \& Foley, J. E. (2009). Meta-Analysis of Coinfection and Coexposure with Borrelia burgdorferi and Anaplasma phagocytophilum in Humans, Domestic Animals, Wildlife, and Ixodes ricinus-Complex Ticks. Vector Borne and Zoonotic Diseases (Larchmont, N.Y.), 9(1), 93-101. http://dx.doi.org/10.1089/vbz.2008.0072. PMid:18789001.

Oliveira, D., Tie Nishimori, C., Costa, M. T., Machado, R. Z., \& Castro, M. B. (2000). Anti-Ehrlichia canis antibodies detection by "Dot-ELISA" in naturally infected dogs. Revista Brasileira de Parasitologia Veterinária, 9, 1-5. 
Oliveira, L. S., Oliveira, K. A., Mourão, L. C., Pescatore, A. M., Almeida, M. R., Conceição, L. G., Galvão, M. A., \& Mafra, C. (2009). First report of Ehrlichia ewingii detected by molecular investigation in dogs from Brazil. Clinical Microbiology and Infection, 15(Suppl2), 55-56. http://dx.doi.org/10.1111/j.1469-0691.2008.02635.x. PMid:19416280.

Parola, P., Socolovschi, C., Jeanjean, L., Bitam, I., Fournier, P. E., Sotto, A., Labauge, P., \& Raoult, D. (2008). Warmer weather linked to tick attack and emergence of severe rickettsioses. PLoS Neglected Tropical Diseases, 2(11), e338. http://dx.doi.org/10.1371/journal.pntd.0000338. PMid:19015724.

Piranda, E. M., Faccini, J. L. H., Pinter, A., Pacheco, R. C., Cançado, P. H., \& Labruna, M. B. (2011). Experimental infection of Rhipicephalus sanguineus ticks with the bacterium Rickettsia rickettsii, using experimentally infected dogs. Vector-borne and Zoonotic Diseases, 11(1), 29-36. http://dx.doi.org/10.1089/vbz.2009.0250. PMID: 20569011.

Ramos, G. S., Zocco, B. K. A., Torres, M. M., Braga, I. A., Pacheco, R. C., \& Sinkoc, A. L. (2015). Helminths parasites of stray dogs (Canis lupus familiaris) from Cuiabá, Midwestern of Brazil. Ciências Agrárias, 36(2), 889-894. http://dx.doi.org/10.5433/1679-0359.2015v36n2p889.

Sales, K. G., Braga, F. R. R., Silva, A. C. F., Muraro, L. S., \& Siqueira, K. B. (2007). Estudo retrospectivo (2006) da erlichiose canina no Laboratório do Hospital Veterinário da Universidade de Cuiabá. Acta Scientiae Veterinariae, 35, s555-s557.

Santos, H. A., Pires, M. S., Vilela, J. A. R., Santos, T. M., Faccini, J. L. H., Baldani, C. D., Thomé, S. M. G., Sanavria, A., \& Massard, C. L. (2011). Detection of Anaplasma phagocytophilum in Brazilian dogs by real-time polymerase chais reaction. Journal of Veterinary Diagnostic Investigation, 23(4), 770-774. http://dx.doi.org/10.1177/1040638711406974. PMid:21908321.

Senghor, M. W., Faye, M. N., Faye, B., Diarra, K., Elguero, E., Gaye, O., Bañuls, A. L., \& Niang, A. A. (2011). Ecology of phlebotomine sand flies in the rural community of mont rolland (Thiès Region, Senegal): area of transmission of canine leishmaniasis. PLoS One, 6(3), e14773. http://dx.doi.org/10.1371/journal.pone.0014773. PMid:21445295.

Signor, C. A., \& Pinho, J. B. (2011). Spatial diversity patterns of birds in a vegetation mosaic of the Pantanal, Mato Grosso. Brazilian Zoology, 28(6), 725-738. http://dx.doi.org/10.1590/S1984-46702011000600005.

Silva, J. N., Almeida, A. B., Boa Sorte, E. C., Freitas, A. G., Santos, L. G., Aguiar, D. M., \& Sousa, V. R. (2010). Soroprevalência de anticorpos anti-Ehrlichia canisem cães de Cuiabá, Mato Grosso. Revista Brasileira de Parasitologia Veterinária,19(2),108-111. http://dx.doi.org/10.1590/S1984-29612010000200008. PMid:20624348.

Silveira, J. A. G., Valente, P. C. L. G., Paes, P. R. O., Vasconcelos, A. V., Silvestre, B. T., \& Ribeiro, M. F. B. (2015). The first clinical ans laboratory evidence of co-infection by Anaplasma phagocytophilum and Ehrlichia canis in a Brazilian dog. Ticks and Tick-Borne Diseases, 6(3), 242-245. http://dx.doi.org/10.1016/j.ttbdis.2015.01.003. PMid:25661650.

Souza, B. M. P. S., Leal, D. C., Barboza, I. D. C. P. M., Uzêda, R. S., Alcântara, I. A. C., Ferreira, F., Labruna, M. B., Gondim, L. F. P., \& Franke, I. C. R. (2010). Prevalence of ehrlichial infection among dogs and ticks in Northeastern Brazil. Revista Brasileira de Parasitologia Veterinária, 19(2), 89-93. http://dx.doi.org/10.1590/ S1984-29612010000200004. PMid:20624344.

Sykes, J. E. (2014). Ehrlichiosis. In J. E. Sykes. Canine and feline infectious diseases (pp. 278-289). St. Louis: Elsevier. http://dx.doi.org/10.1016/B978-1-4377-0795-3.00028-4.

Sykes, J. E., \& Foley, J. E. (2014). Anaplasmosis. In J. E. Sykes. Canine and feline infectious diseases (pp. 290-299), St. Louis: Elsevier. http://dx.doi.org/10.1016/B978-1-4377-0795-3.00029-6.

Vezzani, D., Carbajo, A. E., Fontanarrosa, M. F., Scodellaro, C. F., Basabe, J., Cangiano, G., \& Eiras, D. F. (2011). Epidemiology of canine heartworm in tis southern distribution limit in South America: risk factors, interannual trend and spatial patterns. Veterinary Parasitology, 176(2-3), 240-249. http://dx.doi.org/10.1016/j. vetpar.2010.10.046. PMid:21093157.

Vieira, R. F. C., Biondo, A. W., Guimarães, A. M. S., Santos, A. P., Santo, R. P., Dutra, I. R. H., Diniz, P. P. V. P., Morais, H. A., Messick, J. B., Labruna, M. B., \& Vidotto, I. O. (2011). Ehrlichiosis in Brazil. Revista Brasileira de Parasitologia Veterinária, 20(1), 1-12. http://dx.doi.org/10.1590/S1984-29612011000100002. PMid:21439224.

Villeneuve, A., Goring, J., Marcotte, L., \& Overvelde, S. (2011). Seroprevalence of Borrelia burgdorferi, Anaplasma phagocytophilum, Ehrlichia canis, and Dirofilaria immitis among dogs in Canada. The Canadian Veterinary Journal. La Revue Veterinaire Canadienne, 52(5), 527-530. PMid:22043075.

Willi, L. M. V., Mendes-de-Almeida, F., de Souza, C. D. S. F., Laeta, T., Paiva, J. P., de Miranda, M. G. N., Knackfuss, F. B., \& Labarthe, N. (2017). Serological evidence of canine exposure to arthropode-borne pathogens in different landscapes in Rio de Janeiro, Brazil. Veterinary Parasitology, Regional Studies and Reports, 7, 40-44. http:// dx.doi.org/10.1016/i.vprsr.2016.11.003. PMid:31014655.

World Health Organization - WHO. (2003). Leishmaniasis: influences of climate and climate change, epidemiology, ecology and adaptation measures (Health and Global Environmental Change Series, Vol. 2, pp. 1-32). Copenhagen: WHO Regional Office for Europe. 